\title{
A Study of Phytoplankton Communities and Related Environmental Factors in Euphrates River (between Two Cities: Al-Musayyab and Hindiya), Iraq
}

\author{
Jasim M. Salman ${ }^{1}$, Hassan J. Jawad ${ }^{2}$, Ahmmed J. Nassar ${ }^{1}$, Fikrat M. Hassan ${ }^{3^{*}}$ \\ ${ }^{1}$ College of Science, University of Babylon, Hilla, Iraq; ${ }^{2}$ College of Science, University of Karbala, Holly Karbala, Iraq; ${ }^{3}$ College of \\ Science for Woman, University of Baghdad, Baghdad, Iraq. \\ Email: *fik.has@gmail.com
}

Received July $30^{\text {th }}, 2013$; revised August $28^{\text {th }}, 2013$; accepted September $24^{\text {th }}, 2013$

Copyright (C) 2013 Jasim M. Salman et al. This is an open access article distributed under the Creative Commons Attribution License, which permits unrestricted use, distribution, and reproduction in any medium, provided the original work is properly cited.

\begin{abstract}
The phytoplankton communities and related physical-chemical features of the Euphrates River at its middle region inside Iraqi territory were studied during the study period from October 2011 to September 2012. Samples were taken from Al-Musayab district extending to Al-Hindia district. The phytoplankton community (quantitative, qualitative and Chlorophyll-a) have been studied, in addition to many environmental parameters such as temperature, $\mathrm{pH}$, electric conductivity (EC), Salinity (\%), TDS, TSS, dissolved oxygen, $\mathrm{BOD}_{5}$. A total of 105 phytoplankton taxa belonging to Bacillariophyta (69), Chlorophyta (19), Cynophyta (12), Euglenophyta (3), and Dinophyta (2) were recorded within the present study period. Some algal genera dominated mostly in the study period and sites such as Scendesmus, Melosira, Cymbella, Diatoma, Navicula, Nitiazschia and Syndera. A statistical analysis was done using the canonical correspondence analysis (CCA).
\end{abstract}

Keywords: Phytoplankton; Water Quality; Quantitative and Qualitative Study; Euphrates River; Iraq

\section{Introduction}

Phytoplankton, considered as the basic component of an aquatic food chain, is the source of oxygen and the main autochthonous primary producers [1]. The floristic variation in phytoplankton community depends on the availability of nutrients, temperature, light intensity and on other limnological factors [2]. Phytoplankton is one of the major biological elements used for the assessment of the ecological status of surface water bodies, and the variation in the biotic parameters provides a good indication of energy turnover in aquatic environments, due to its sensitivity to any change in the environment $[3,4]$. Many authors emphasized the importance of phytoplankton as bioindictors in different aquatic systems [5-7].

Many previous researches on the Euphrates River showed the phytoplankton composition and the effect of lotic characteristics especially in the south of Iraq [8-10]. Few studies worked on the middle region of the Euphrates River inside Iraq [11-15].

The present study aims at filling the gap of informa-

${ }^{*}$ Corresponding author. tion on phytoplankton communities and water quality of the studied area.

\section{Materials and Methods}

The present study area was chosen along the Euphrates River, middle of Iraq, between al-Musayab city (near the northern of Al-Hindiya barrage) to Al-Hindiya city (formerly Twareej: near the southern holy city of Karbala). The three sites were chosen in this area (Figure 1).

The current study was carried out from October 2011 to September 2012. Physical and chemical properties of the river water (Temperature, $\mathrm{PH}$, electrical conductivity, salinity, TDS, TSS, dissolved oxygen, BOD5) were measured according to [16], chlorophyll-a study site was measured [17].

Phytoplankton was collected from the sampling sites with plankton net $[18,19]$ for qualitative study, while a sedimentation technique was used for quantitative study. The micro transect methods were used for counting diatoms, and hemocytometer methods for other groups [20]. Identification of the phytoplankton was done by following references [21-26]. The statistic analyses were done 


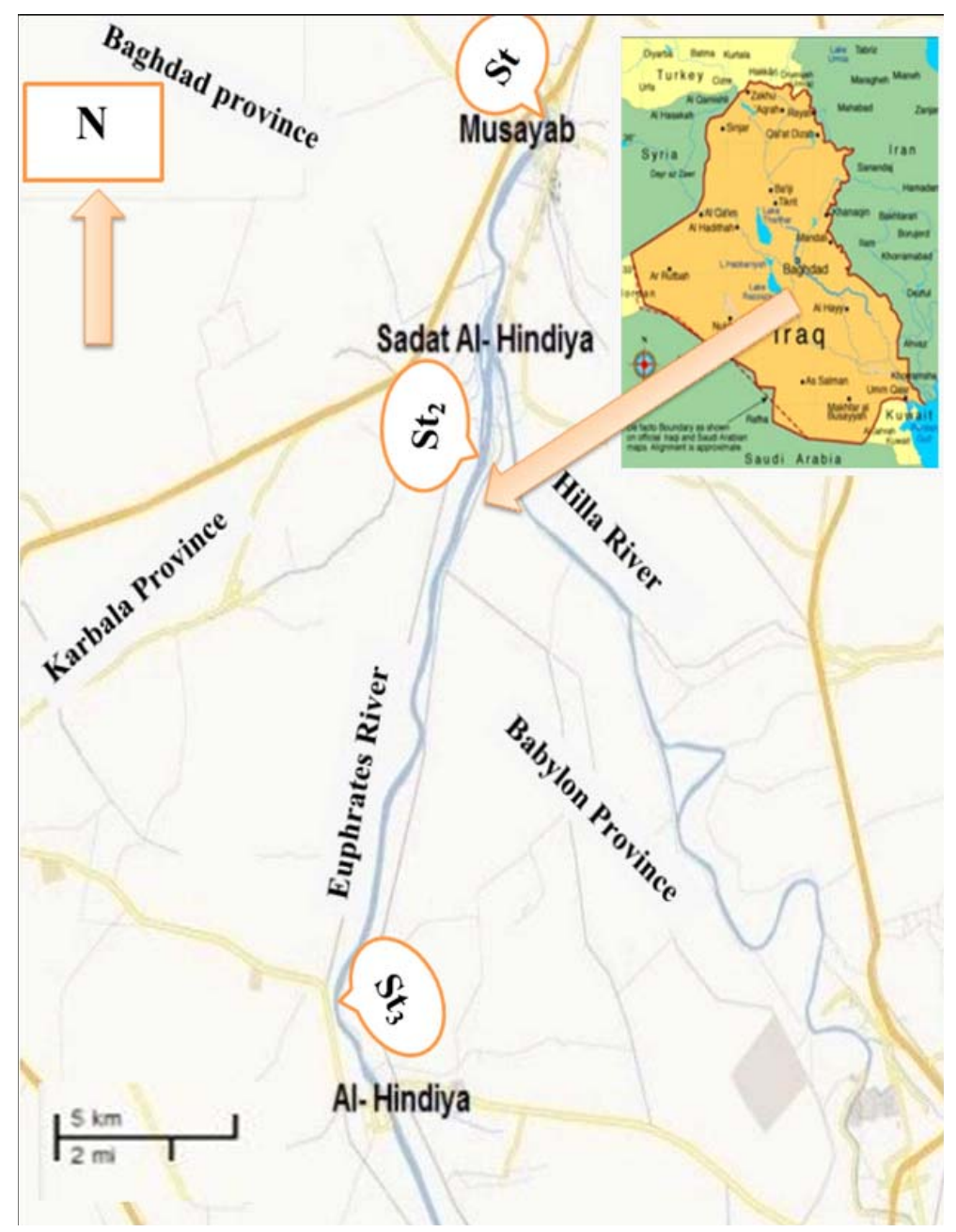

Figure 1. Map of the study area in Euphrates River at its mid region, Iraq.

by using correlation coefficient (r), and canonical correspondence analysis (CCA). CCA method was conducted by using the computer program CANOCO, version 4.5 in order to clarify the relationships between water quality parameters and phytoplankton species.

\section{Results and Discussion}

The environmental characteristic of the water in the study area is shown in Table 1. The air temperature reached its high value $\left(43.5^{\circ} \mathrm{C}\right)$ in Site 3 and its lowest value $\left(9^{\circ} \mathrm{C}\right)$ in Site 2 , while the water temperature ranged between 9.06 to 31.43 in sites 2 and 3 respectively. Narrow fluctuation of $\mathrm{pH}$ was observed during the study period, with the highest average value of 8.7 and a low of 7.3; this observed variation was statics significant between month ( $p$ $\leq 0.05)$ but not between the sites $(\mathrm{p} \leq 0.05)$. $\mathrm{pH}$ variation might be caused by discharge of waste water, photosynthesis and other metabolic process [27], and may be attributed to introduction of silt into the river by rain water or due to the mixing of the fast flowing water as it moves down stream [28]. These results match with many other studies of [11,15,28-32].

The results showed high conductivity values ranged between $\left(798.7 \mu \mathrm{s}^{\cdot} \mathrm{cm}^{-1}\right)$ in site 1 as lower value and $\left(1168.6 \mu \mathrm{s} \cdot \mathrm{cm}^{-1}\right)$ in site 2 as high value, while water salinity in study area ranged between $(0.5 \%-0.7 \%)$. The increasing values of conductivity and salinity in Euphrates River may be of the discharge of agricultural and industrial wastewater [13].

The total dissolved solid (TDS) followed the trend as conductivity temporarily and spatial. It ranged from 502 . 33 to $789.3 \mathrm{mg} / \mathrm{l}$, while the value of TSS ranged between 0.01 to $0.3 \mathrm{mg} / \mathrm{l}$. Many factors affecting the transparency of water such as silting, microscopic organisms and suspended organic matter [32] and this variation can be explained by a higher nutrient dynamics in the water column [33].

High concentration of dissolved oxygen was recorded in the present study. This concentration ranged from 6.2 
Table 1. Some physical \& chemical properties of water in Euphrates river from October 2011 to September 2012 (First line: average, Second line: mean $\pm \mathrm{SD})$.

\begin{tabular}{cccc}
\hline Parameters & \multicolumn{1}{c}{ Sites } & 3 \\
\cline { 2 - 3 } Air temp $\left({ }^{\circ} \mathrm{C}\right)$ & 1 & 2 & $13.33-43.5$ \\
& $11.7-39.27$ & $23 \pm 9.34$ & $26.53 \pm 8.86$ \\
Water temp $\left({ }^{\circ} \mathrm{C}\right)$ & $22.27 \pm 7.76$ & $9.06-29.96$ & $13.03-31.43$ \\
& $11.54-30.37$ & $20.08 \pm 6.85$ & $21.09 \pm 6.23$ \\
$\mathrm{pH}$ & $19.73 \pm 6.69$ & $8.7-7.3$ & $7.6-8.7$ \\
& $7.6-8.7$ & $8.18 \pm 057$ & $8.29 \pm 0.34$ \\
E.C $(\mu \cdot \mathrm{S} / \mathrm{cm})$ & $8.26 \pm 0.34$ & $811.1-1168.6$ & $903-1149$ \\
& $798.7-1167.6$ & $974.6 \pm 114.36$ & $1011.4 \pm 95.33$ \\
Salinity $(\mathrm{o} \%)$ & $961.17 \pm 127.16$ & $0.521-0.747$ & $0.577-0.736$ \\
& $0.511-0.746$ & $0.621 \pm 0.073$ & $0.646 \pm 0.062$ \\
TDS $(\mathrm{Mg} / \mathrm{L})$ & $0.614 \pm 0.081$ & $502.33-739$ & $572-789.3$ \\
& $540.22-758.44$ & $624 \pm 64.81$ & $651 \pm 76$ \\
TSS $(\mathrm{Mg} / \mathrm{L})$ & $641.1 \pm 68.71$ & $0.06-0.323$ & $0.063-0.031$ \\
& $0.0104-0.0443$ & $0.0172 \pm 0.0069$ & $0.0176 \pm 0.00754$ \\
DO $(\mathrm{Mg} / \mathrm{L})$ & $0.0226 \pm 0.0209$ & $6.27-11.59$ & $6.63-10.78$ \\
BOD $(\mathrm{mg} / \mathrm{L})$ & $6.9-11.38$ & $8.96 \pm 1.52$ & $8.44 \pm 1.3$ \\
Chlorophyll-a & $8.69 \pm 1.4$ & $0.94-4.04$ & $1.05-3.86$ \\
$(\mu \mathrm{g} / \mathrm{L})$ & $1.28-4.216$ & $2.9 \pm 1$ & $2.25 \pm 0.94$ \\
Total algae $\left(\mathrm{cell} / \mathrm{cm}{ }^{3}\right)$ & $2.33 \pm 1.1$ & $0-13.29$ & $0-24.37$
\end{tabular}

$\mathrm{mg} / 1$ to $11.59 \mathrm{mg} / \mathrm{l}$. There was an increase in dissolved oxygen in cold months at all the study sites. The concentration of dissolved oxygen was affected by many factors especially biological activities such as photosynthetic, respiration and decomposition process at the river bottom in addition to the rainfall effects [34-36]. The dissolved oxygen concentration was found to be within the (5 - 9) $\mathrm{mg} / \mathrm{l}$, which was limited for drinking water [37].

The concentrations of $\mathrm{BOD}_{5}$ ranged from $0.94 \mathrm{mg} / \mathrm{l}$ to $4.22 \mathrm{mg} / \mathrm{l}$ in site 2 and site 1 respectively, these results showed acceptance values of BOD5 according to (APHA, 2003). These concentrations may be attributed to the observed human activities such as washing, dumping of refuse and discharge of sewage into the river [38]. The lower concentrations of BOD5 may be due to the selfpurification of river [39]. The recorded BOD5 in this study indicated that the studied river is classified as unpolluted to moderately polluted, Adakole et al. [40] revealed that the $\mathrm{BOD}_{5}$ values ranged between $>1.0$ to $<10.0 \mathrm{mg} / \mathrm{l}$ was considered as unpolluted to moderately polluted water. BOD is referred to the amount of biodegradable organic materials [41], and its values refer to associated with wastewater concentration [37].

Phytoplankton biomass, as chlorophyll-a, has been measured at least once monthly in all study sites, chlorophyll-a concentrations ranged between N.D in site 2 as lower value and $24.37 \mathrm{mg} / \mathrm{l}$ in site 3 as higher value. The species composition has a big effect on chlorophyll-a concentration in an aquatic systems and low concentration of chlorophyll-a was recorded (Table 2), might be due to dominate of diatoms in high number compared with other algal groups [42], and the changes in biomass of phytoplankton have been associated with increased temperature and decreased water discharge [43]. The variation of chlorophyll-a concentrations was highly correlated with phytoplankton density and water quality in the present study sites [44]. Clear peaks were observed in late spring and autumn. Similar results were found in many Iraqi aquatic system studies $[12,30,45]$.

Phytoplankton community of Euphrates River in the present study sites from October 2011 to September 2012 consisted of a total of (105) taxes (Table 3) belonging to five taxonomical division; Bacillariophyta (69), Chlorophyta (19), Cyanophyta (12), Euglenophyta (3) and Dinophyta (2). The total numbers of phytoplankton ranged between $216 \mathrm{cell} / \mathrm{cm}^{3}$ to $4565 \mathrm{cell} / \mathrm{cm}^{3}$ in sites 2 and 1 during March 2012 and October 2011 respectively (Table 2). High yearly density of Phytoplankton recorder in site $1\left(19,214 \mathrm{cell} / \mathrm{cm}^{3}\right)$ and low yearly density in site 2 $\left(15,327 \mathrm{cell} / \mathrm{cm}^{3}\right)$ during the study period, might be due to availability of environmental condition for phytoplankton growth [46]; phytoplankton density which can be explained by the increase of nutrients in the environment [42], suggests that a high density of phytoplankton recorded for the first sampled point may be associated with nutrients and low water current before Al-Hindia 
Table 2. Total numbers of phytoplankton $\left(\mathrm{cell} / \mathrm{cm}^{3}\right)$ in study sites from October 2011 to September 2012.

\begin{tabular}{|c|c|c|c|c|c|c|c|c|c|c|c|c|c|}
\hline \multirow{2}{*}{ Sites } & \multicolumn{3}{|c|}{$\rightarrow 2011 \leftarrow$} & \multicolumn{9}{|c|}{$\rightarrow 2012 \leftarrow$} & \multirow[b]{2}{*}{ Total } \\
\hline & Oct & Nov & Dec & Jan & Feb & Mar & Apr & May & Jun & Jul & Aug & Sep & \\
\hline 1 & 4565 & 2393 & 819 & 514 & 1115 & 318 & 395 & 785 & 1944 & 613 & 1300 & 4453 & 19,214 \\
\hline 2 & 3900 & 2221 & 712 & 450 & 816 & 216 & 320 & 514 & 955 & 711 & 1112 & 3400 & 15,327 \\
\hline 3 & 4210 & 2111 & 701 & 510 & 1022 & 413 & 385 & 716 & 1714 & 610 & 1150 & 4100 & 17,642 \\
\hline
\end{tabular}

Table 3. List of identified phytoplankton species in Euphrates River-Middle of Iraq (2011-2012).

\begin{tabular}{|c|c|c|c|}
\hline Taxa & $\mathrm{S} 1$ & $\mathrm{~S} 2$ & S3 \\
\hline \multicolumn{4}{|l|}{ Cyanophyceae } \\
\hline AnabeanabergiiOstenf & + & - & - \\
\hline Chroococcusminuteus (Ktz.) Naegeli & + & + & + \\
\hline Chroococcusturgidus (Ktz.) Naegeli & + & + & + \\
\hline Gloeocapsa Sp. & - & - & + \\
\hline Merismopediaelegans (A.) Braum & + & + & + \\
\hline Merismopediaglauca (Ehr.) Naegeli & + & + & + \\
\hline MicrocystisaeruginosaKuetzing & + & + & - \\
\hline Nostoc SP. & + & - & - \\
\hline Oscillatoria articulate Gardnar & + & - & - \\
\hline OscillatoriachalybeaMertens & - & - & + \\
\hline Oscillatoria sancta (Ktz.) Gomont & + & + & + \\
\hline SpirolinalaxaG.M.Smith & + & - & - \\
\hline \multicolumn{4}{|l|}{ Chlorophyceae } \\
\hline ActinostrumhantizschiiLagerhein & + & - & - \\
\hline Ankistrodesmusfalcatus (Corda) Ralfs & + & - & + \\
\hline Carteriaklebsii (Dang) Dill & - & - & + \\
\hline Chlamydomonasangulosa Dill & - & + & - \\
\hline Chlorella vulgaris Bejerinck & + & + & + \\
\hline Oedogonium SP. & - & - & + \\
\hline Pediastrum duplex Meyen & + & + & + \\
\hline Pediastrum Simplex Meyen & + & + & - \\
\hline Scenedesmusdimorphus (Turb.) Lagher & + & + & - \\
\hline ScenedesmuslongusMeyen & - & - & + \\
\hline Scenedesmusquadricauda (Turb.) de Brebisson & + & + & + \\
\hline Scenedesmusbijuga (Turb.) Laghere & - & + & - \\
\hline Spirogera SP. & + & - & - \\
\hline Spirogyra fluviatilis Hila & - & - & + \\
\hline Staurastrumalternans & + & - & - \\
\hline StaurastrumSP. & + & - & - \\
\hline Tetraedronhastatum (Reisch) Hansg & + & - & + \\
\hline Tetraedron regular Ktz. & + & - & + \\
\hline Ulothrixzonata (Webre and Mohr) Ktz. & - & + & - \\
\hline \multicolumn{4}{|l|}{ Euglenophyceae } \\
\hline Euglena acusEhernberg & + & - & + \\
\hline EuglengracilisKlebs & + & + & - \\
\hline Trachelomonas SP. & - & - & + \\
\hline \multicolumn{4}{|l|}{ Dinophyceae } \\
\hline Ceratiumhirundrnella (Muell,) Du Jardin & + & + & + \\
\hline Peridiniumcinctum (Muell,) Ehernberg & - & - & + \\
\hline
\end{tabular}


A Study of Phytoplankton Communities and Related Environmental Factors in Euphrates River (between Two Cities: Al-Musayyab and Hindiya), Iraq

\section{Continued}

\begin{tabular}{|c|c|c|c|}
\hline \multicolumn{4}{|l|}{ Bacillariophyceae } \\
\hline \multicolumn{4}{|l|}{ Order Centrales } \\
\hline CyclotellaatomusGrunow & + & - & - \\
\hline Cyclotellacomta (Ehr.) Kuetzing & + & - & + \\
\hline CyclotellameneghinianaKuetzing & + & + & + \\
\hline CyclotellaocellataPantocsek & + & - & + \\
\hline Melosira granulate (Ehr.) Ralfs & + & + & + \\
\hline MelosiravariansAgradh & - & - & + \\
\hline \multicolumn{4}{|l|}{ Order Pennales } \\
\hline Amphora ovalis(Ktz.) Kuetzing & - & - & + \\
\hline Amphora SP. & + & - & - \\
\hline Amphora venetaKuetzing & + & - & + \\
\hline Asterionella Formosa & + & + & - \\
\hline Bacillariafaxillifer (Muell,) Hendey & + & + & + \\
\hline Caloneis amphisbaena (Bory) Cleve & - & - & + \\
\hline Caloneispermagna (Bail) Cleve & + & - & - \\
\hline CocconeispediculusEhernberg & + & + & + \\
\hline CocconeisplacentulaEhernberg & + & + & + \\
\hline Cymatopleurasolea (Berb.) W. Smith & + & - & - \\
\hline Cymbellalanceolata (Ehr.) & + & - & + \\
\hline CymbellaaffinisKuetzing & + & + & + \\
\hline Cymbellaaspera (Ehr.) H.Paragallo & + & - & + \\
\hline Cymbellacistula (Ehr.) Kirchn & + & + & + \\
\hline Cymbellagracilis & - & - & + \\
\hline CymbellahelveticaKuetzing & + & - & - \\
\hline Cymbellaparva (W.Smith) Kirchn & - & + & + \\
\hline Cymbellatumida (Berb.) Van Heurck & + & + & + \\
\hline Cymbellaturgid (Greg) Cleve & + & + & + \\
\hline Diatomahiemale (Roth.) Heiberg & + & - & - \\
\hline DiatomavulgareBory & + & + & + \\
\hline Diploneisovalis (Hilse) Cleve & - & + & + \\
\hline DiploneissmithiiBory & + & + & + \\
\hline Eutoniacurvata & + & - & - \\
\hline EutoniamonodonEhr & - & - & + \\
\hline FlagilariacapucinaDesmazieres & + & + & - \\
\hline FlagilariacrotonensisKitton & + & + & + \\
\hline FlagilariaintermediaGrunow & + & - & - \\
\hline Gomphonema. constricumEhernberg & + & + & + \\
\hline G. fanensisMaillard & + & + & + \\
\hline G. gracileEhernberg & + & - & - \\
\hline G.angustatum (Ktz.) Rabenhorst & + & + & + \\
\hline G.parvulum (Ktz.) Kuetzing & - & - & + \\
\hline Gomphoneisolivaceum (Horne) P.Dawson ex Ross et Smith & + & + & + \\
\hline GomphonemaacuminatumEhernberg & + & + & + \\
\hline Gyrosigmaacuminatum (Ktz.) Rabenhorst & + & - & - \\
\hline MstogloiasmithiiThw.Ex.W.Sm & + & + & + \\
\hline Naviculacincta (Ehr.) & + & - & - \\
\hline N.anglicaRalfs & + & + & + \\
\hline N.gracile (Ehr.) & + & + & + \\
\hline
\end{tabular}




\begin{tabular}{|c|c|c|c|}
\hline N.pupulaKuetzing & + & - & - \\
\hline N.pygmaeaKuetzing & + & - & - \\
\hline N.viridulaKuetzing & - & - & + \\
\hline Neidium affine (Ehr.) Pfitz & + & + & + \\
\hline Ni. CommutateGrunow & - & + & + \\
\hline Ni.amphibiaaGrunow & + & + & + \\
\hline Ni.dissipata (Ktz.) Grunow & + & + & + \\
\hline Hantzsch Ni.gracilis & + & + & + \\
\hline Ni.hantizschianaRabenhorst & + & + & + \\
\hline Ni.hungaricaGrunow & + & + & + \\
\hline Ni.linearisW.Smith & + & + & + \\
\hline Ni.palea (Ktz.) W.Smith & + & + & + \\
\hline Ni.rectaHantzsch ex Rabenh & + & + & + \\
\hline Ni.sigma (Ktz.) W.Smith & + & - & - \\
\hline Nitiazschiaacicularis (Ktz.) W.Smith & + & + & + \\
\hline P.viridis (Nitzsch.) Ehernberg & - & - & + \\
\hline PinnulariadiverginsEhr & + & + & + \\
\hline Rhoicospheniacurvata (Ktz.) Grunow & + & + & + \\
\hline S. tenera Gregory & + & - & - \\
\hline S.capitataEhernberg & + & - & - \\
\hline S.ulnaNitzsch. Ehernberg & + & + & + \\
\hline SurirellaelegansEhr & + & - & - \\
\hline SynedraacusKuetzing & + & + & + \\
\hline
\end{tabular}

barrage; moreover, the effect of the barrage on phytoplankton density before (site 1) and after (sites 2 and 3 ) is clear [45].

Bacillariophyta were found in high percentage $(65.7 \%)$ of total organisms and they were dominating species among the algal groups (Figure 2). Bacillariophyta was dominant followed by Chlorophyta, Cynophyta, Euglenophyta, and Dinophyta (Table 3). In the present study the river water showed a higher population of diatoms coincided with the higher dissolved oxygen through the study period, in general, the requirement of dissolved oxygen for growth of many diatom species is well documented [43]. Pennales diatom was the dominated group of diatoms (63 species) in the present study, this might be due to high tolerance to wide environmental changes $[1,32,47]$.

The present study results showed the dominate of some genera of phytoplankton on a long study period, such as Scendesmus, Melosira, Cymbella, Diatoma, Navicula, Nitzschia, Synedra, these results were recorded by other studies $[1,2,36,38]$. Phytoplankton densities tended to increase during the months of spring and summer, which can be explained by the increase of nutrients in the environment, especially nitrogen and phosphorus [42]. Euglenophyta and Dinophyta species were very view in a number ( 3 and 2 species respectively), and their percentage composition value was low: $2.85 \%$ and $1.9 \%$ respectively. In general, the existence of Euglenophyta species

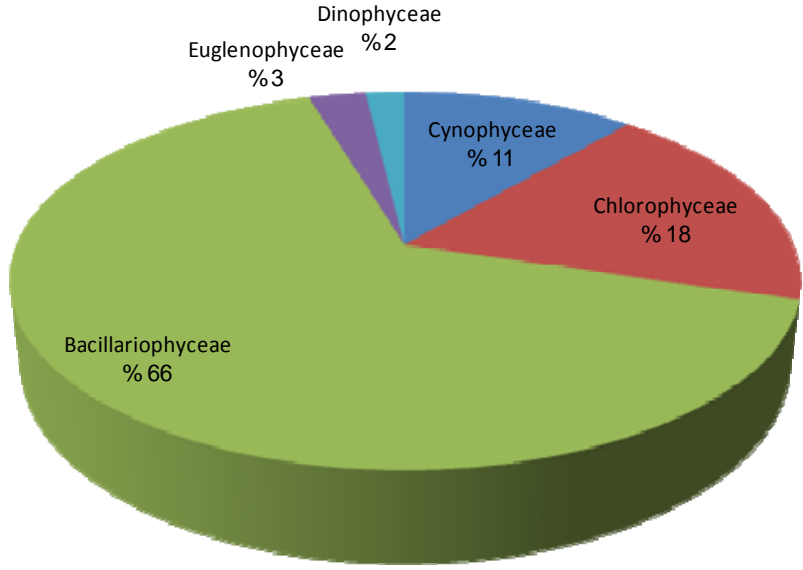

Figure 2. Species abundance of phytoplankton class in Euphrates river.

refers to organic pollution of aquatic system [2].

CCA for water quality and phytoplankton in the present study (Figure 3) indicated that negative relationships found between air and water temperature, salinity, TDS, BOD5 and phytoplankton, while, positive relationships were observed between phytoplankton and DO, chlorophyll-a, PH, and TDS. The interaction between various physical, chemical and biological factors is the causative regulator for seasonal variation and standing crop of phytoplankton [48]. The positive correlation of 


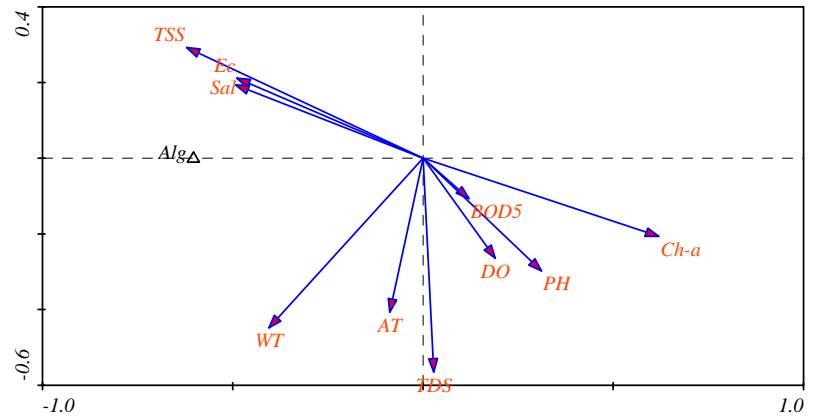

Figure 3. Correlations between water quality parameters and phytoplankton according to Canoco (CCA).

some water properties with phytoplankton density may be due to playing a pivotal role in regulation various biological activities and growth [2].

\section{Conclusion}

The present study results revealed that temperature, salinity, DO and BOD5 were playing important roles as limited factors to phytoplankton in this study. The variation in the functional groups of phytoplankton reflects the seasonal dynamics of revering Phytoplankton and the impact of water quality.

\section{Acknowledgements}

We are grateful to Department of Biology, College of Science, University of Babylon for their support to this research.

\section{REFERENCES}

[1] M. Shams, S. Afsharzadeh and T. Atici, "Seasonal Variations in Phytoplankton Communities in Zayandeh-Rood Dam lake (Isfahan, Iran)," Turkish Journal of Botany, Vol. 36, 2012, pp. 715-726.

[2] S. Ghosh, S. Barinora and J. P. Kesh, "Diversity and Seasonal Variation of Phytoplankton Community in the Santragachi Lake, West Bengal, India," Qscience Connect, 2012:3

[3] C. Forsberg, "Limnological Research Can Improve and Reduce the Cost of Monitoring and Control of Water Quality," Hydrobiologia, Vol. 86, No. 1-2, 1982, pp. 143146. http://dx.doi.org/10.1007/BF00005801

[4] C. Reynolds, "Ecology of Phytoplankton," Cambridge University Press, Cambridge, 2006. http://dx.doi.org/10.1017/CBO9780511542145

[5] F. H. Aziz, D. G. A. Ganjo and Y. A. Shekha, "Observation on the Limnology of Polluted Pond in Erbil City, Iraq," ZANCO, Vol. 5, No. 4, 2003, pp. 23-30.

[6] F. H. Aziz, "Algae Assemblages as Biological Indictors for Freshwater Quality Assessment," Journal of University of Duhok, Pure and Engineering Sciences, Vol. 12, No. 1, 2009, pp. 15-20.
[7] E. G. Bellinger and D. C. Sigee, "Freshwater Algae: Identification and Use as Bioindicators," Johan Wiley \& Sons, Ltd., Hoboken, 2010. http://dx.doi.org/10.1002/9780470689554

[8] R. A. M. Hadi, A. Al-Sabonchi and A. K. Y. Haroon, "Diatoms of the Shatt Al-Arab River Iraq," Nova Hedwigia, Vol. 39, 1984, pp. 513-557.

[9] A. Y. Al-Handal, A. R. M. Mobdhamad and D. S. Abdulla, "The Diatom Flora of the Shatt Al-Arab Canal, South Iraq," Marina Mesopotamica, Vol. 6 No. 2, 1991, pp. 169-181.

[10] A. A. Al-Lami, H. A. Al-Saadi, T. I. Kassim and R. K. Farhan, "Seasonal Change Epipelic Algae Communities in North Part of Euphrates River, Iraq," Journal of College of Education For Women, University of Baghdad, Vol. 10, No. 2, 1999, pp. 236-247.

[11] F. M. Hassan, "A Limnological Study on Hilla River," Al-Mustansiriya Journal of Science, Vol. 8, 1997, pp. 2230.

[12] F. M. Hassan, N. F. Kathim and F. A. Hussein, "Effect of Chemical and Chemical Properties of River Water in Shatt Al-Hilla on Phytoplankton Communities," E-Journal of Chemistry, Vol. 5, No. 2, 2008, pp. 323-330. http://dx.doi.org/10.1155/2008/940542

[13] F. M. Hassan, M. M. Saleh and J. M. Salman, "A Study of Physic Chemical Parameters and Nine Heavy Metals in Euphrates River, Iraq," E-Journal of Chemistry, Vol. 7, No. 3, 2010, pp. 685-692.

[14] H. J. J. Al-Fatlawi, "Environmental Study of Algal Community in Euphrates River between Al-Hindia City to AlManathere City Region, Iraq," Ph.D. Thesis, College of science, University of Babylon Iraq, 2011.

[15] F. M. Hassan, W. D. Talyor, M. S. Al-Taee and H. J. J. Al-Fatlawi, "Phytoplankton Composition of Euphrates River in Al-Hindiya Barrage and Kifil City Region of Iraq," Journal of Environmental Biology, Vol. 31, 2010, pp. 343-350.

[16] APHA (American Public Health Association), "Standard Methods for the Examination of Water and Waste Water," 20th Edition, APHA, Washington DC, 2003.

[17] A. Aminto and F. Rey, "Standard Procedure for the Determination of Chlorophyll a by Spectroscopic Method," International Council for the Exploration of the Sea, Techniques in Marine Environmental Science, 2000, 16 p.

[18] T. R. Parsons, Y. Mait and C. M. Laulli, "A Manual of Chemical and Biological Methods for Seawater Analysis," Pergamone Press, Oxford, 1984.

[19] G. Chopra, A. K. Tyor and S. Kumari, "Assessment of Seasonal Density Variation of Phytoplanktons in Shallow Lake of Sultanpur National Park, Gurgoaon, Haryana, India," The Journal of Biodiversity, Vol. 112, 2013, pp. 227-232.

[20] R. A. Vollenweider, "A Manual on Methods for Measuring Primary Production Aquatic Environments," Blackwell Scientific Publication Ltd., Oxford, 1974, 225 p.

[21] G. W. Prescott, "Algae of Western Great Lake Area," William, C. Brown Co. Publ., Dubuque, 1982. 
[22] N. Foged, "Fresh Water Diatoms in Serilanka (Ceylon) Bibliotheca Phycologi," Herausgeben Von J. Cramer Bond, 1976.

[23] F. Hustedt, "The Pinnate Diatoms," An English Translation of Husted F. Dickiselal genteliz, Jensen Iv. Kocwingstein, Gylcoeltz, Sci., Books, 1985.

[24] T. V. Desikachary, "Cynophyta," Indian Council of Agriculture Research, New Delhi, 1959, 686 p.

[25] A. Y. Al-Handal, "Contribution to the Knowledge of Diatoms of Sawa Lake, Iraq," Nova Hedwiia, Vol. 59, No. 12, 1994, pp. 22-254.

[26] F. M. Hassan, R. W. Hadi, T. I. Kassim and J. S. AlHassany, "Systematic Study of Epiphytic Algal after Restoration of Al-Hawizah Marshes, Southern of Iraq," International Journal of Aquatic Science, Vol. 3, No. 1, 2012, pp. 37-57.

[27] Y. Tanimu, S. P. Bako, J. A. Adakole and J. Tanimu, "Phytoplankton as Bioindicators of Water Quality in Saminaka Reservoir Northern Nigeria," Proceeding of International Symposium on Environmental Science and Technology, Dongguan, 2011.

[28] A. M. Zakariya, M. A. Adelanwa and Y. Tanimu, "Physico-Chemical Characteristics and Phytoplankton Abundance of the Lower Niger River, Kogi State, Nigeria," IOSR Journal of Environmental Science, Toxicology and food Technology, Vol. 2, No. 4, 2013, pp. 31-37.

[29] H. A. Al-Saadi, F. M. Hassan and F. M. Alkam, "Phytoplankton and Related Nutrients in Sawa Lake, Iraq," Journal of Dohuk University, Vol. 11, No. 1, 2008, pp. 67-76.

[30] J. M. Salman, F. M. AlKam and H. J. Al-Fatlawi, "A Biodiversity of Phytoplankton in Euphrates River, Middle of Iraq," Iraqi Journal of Science, Special Issue 1st Conference of Biology, University of Baghdad, 6-7 March 2012, pp. 277-293.

[31] J. M. Salman and H. A. Hussain, "Water Quality and Some Heavy Metals in Water and Sediment of Euphrates river, Iraq," Journal of Environmental Science and Engineering, Vol. 1, No. 9, 2012, pp. 1088-1095.

[32] A. A. Ayoade, N. K. Agarwal and A. Chandola-Saklani, "Changes in Physicochemical Features and Plankton of Two Regulated High Altitude Rivers Garhwal Himalaya, India," European Journal of Scientific Research, Vol. 27, No. 1, 2009, pp.77-92.

[33] A. P. P. Carralho, T. Zhonghua, M. M. F. Correia and J. P. Neto, "Study of Physical-Chemical Variables and Primary productivity in Bacanga River Estuary Dam, Saoluis, Maranhao, Brazil," Researcher, Vol. 2, No. 2, 2012, pp. $15-24$.

[34] N. F. Olele and J. K. Ekelemu, "Physicochemical and Periphyton/Phytoplankton Study of Onah Lake, Asaba, Nigeria," African Journal of General Agriculture, Vol. 4, No. 3, 2008, pp. 183-193.

[35] A. Campanelli, A. Bulatoric and M. Cabrini, "Spatial Distribution of Physical, Chemical and Biological Oceanographic Properties, Phytoplankton, Nutrients and Coloured Dissolved Organic Matter (CDOM) in the Boka Ko- torska Bay (Adriatic Sea)," GEDFIZIKA, Vol. 26, No. 2, 2009, pp. 215-228.

[36] A. S. Amer and H. A. Abd El-Gawad, "Rapid Bio-Indicators Assessment of Macrobiotic Pollution on Aquatic Environment," International Water Technology Journal, Vol. 2, No. 3, 2012, pp. 196-206.

[37] UNESCO-WHO-UNEP, "Water Quality Assessment-A Guide to the Use of Biota, Sediments and Water in Environmental Monitoring," E and FN Spon, Cambridge, 1996.

[38] M. A. Essien-Ibok and I. A. Umoh, "Seasonal Association of Physic-Chemical Parameters and Phytoplankton Density in Mboriver, Akwa Ibom State, Nigeria," IACS TT International Journal of Engineering and Technology, Vol. 5, No. 1, 2013, pp. 146-148.

[39] K. Piirsoo, P. Pall, A. Tuvikene, M. Viik and S. Vilbaste, "Assessment of Water Quality in a Large Lowland River (Narva, Estonia, Russia) Using a New Hungarian Potamo Planktonic Method," Estonian Journal of Ecology, Vol. 59, No. 4, 2010, pp. 243-258.

[40] J. A. Adakole, J. K. Balogun and A. K. Haroon, "Water Quality Impacts Assessment Associated with an Urban Stream in Zaria, Nigeria," Journal for the Nigerian Society for Experimental Biology, Vol. 2, No. 3, 1984, pp. 195-203.

[41] A. N. P. I. Amadi, E. A. Olasehinde, E. A. Okosun and J. Yisa, "Assessment of the Water Quality Index of Otamiri and Oramiriukwa Rivers," Physics International, Vol. 1, No. 2, 2010, pp. 116-123.

[42] A. P. P. Carvalho, T. Zhonghua, M. M. F. Correia and J. P. C. Neto, "Study of Physical-Chemical Variables and Primary Productivity in Bacanga River Estuary Dam, Sao Luis, Maranhao, Brazil," Researcher, Vol. 2, No. 2, 2010, pp. 15-24.

[43] M. M. Ramesha and S. Sophia, "Species Composition and Diversity of Plankton in the River Seata at Seetanadi, the Western Ghats, India," Advanced BioTech, Vol. 12, No. 8, 2013, pp. 20-27.

[44] S. Matijevic, G. Kuspilic, M. Morovic, B. Grbec, D. Bogner, S. Skejic and J. Veza, "Physical and Chemical Properties of Water Column and Sediments at Sea Bass/ Sea Bream Farm in the Middle Adriatic (Maslinora Bay)," Acta Adriatica, Vol. 50, No. 1, 2009, pp. 59-76.

[45] F. M. Hassan, J. M. Salman and A. S. Naji, "Water Quality and Phytoplankton Composition in Al-Hilla River, Iraq," Proceeding of 4th Conference of Environmental Science, University of Babylon, Babylon, 5-6 December 2012, pp. 144-160.

[46] T. T. Rajagopal, I. A. Thangamani and G. Archunanl, "Comparison of Physic-Chemical Parameters and Phytoplankton Species Diversity of Two Perennial Ponds in Sattur Area, Tamil Nadu," Journal of Environmental Biology, Vol. 31, No. 5, 2010, pp. 787-794.

[47] C. A. Journey, K. M. Beaulieu and P. M. Bradley, "Environmental Factors that Influence Cyanobacteria and Geosmin Occurrence in Reservoirs. Current Perspectives in Contaminant Hydrology and Water Resources Sustainability," 2013. 

(between Two Cities: Al-Musayyab and Hindiya), Iraq

[48] A. A. H. El-Gindy and M. M. Dorham, "Interaction of Phytoplankton Chlorophyll and Physic-Chemical Factors in Arabian Gulf and Gulf of Oman during Summer," In- dian Journal of Marine Sciences, Vol. 21, No. 1, 1992, pp. 233-306. 